\title{
ERRATUM
}

Lydia Maria Lobato · Luiz Cláudio Ribeiro-Rodrigues

Frederico Wallace Reis Vieira

\section{Brazil's premier gold province. Part Il: geology and genesis of gold deposits in the Archean Rio das Velhas greenstone belt, Quadrilátero Ferrífero}

Published online: 20 September 2001

(C) Springer-Verlag 2001

\section{Mineralium Deposita (2001) 36:249-277}

In the original publication of this article, Fig. 1 was unfortunately omitted. Figure 1 can be seen here.

The online version of the original article can be found at http://dx.doi.org/10.1007/s001260100180

L.M. Lobato

Departamento de Geologia, IGC-CPMTC,

Universidade Federal de Minas Gerais,

Av. Antônio Carlos 6627, Pampulha,

Belo Horizonte, Minas Gerais, 31270-901, Brazil

E-mail: lobato@igc.ufmg.br

Fax: + 55-31-4995410

L.C. Ribeiro-Rodrigues

FAPEMIG Bursary Recipient, Escola de Minas,

Universidade Federal de Ouro Preto,

Morro do Cruzeiro, Ouro Preto,

Minas Gerais, 35400-000, Brazil

F.W.R. Vieira

Mineração Morro Velho Ltda.,

Fazenda Rapaunha s/ no., Nova Lima,

Minas Gerais, 34000-000, Brazil

Present address: L.C. Ribeiro-Rodrigues

Fundação Educacional de Caratinga (FUNEC),

Av. Moacyr de Mattos 49, Centro,

Caratinga, Minas Gerais, 35300-047, Brazil 
Fig. 1 Simplified geological map of the region surrounding Nova Lima, with location of gold deposits mentioned in the text (modified after Vieira and Oliveira 1988, and adapted according to Zucchetti and Baltazar 1998. Nova Lima rock

associations adapted from the work by Baltazar and Pedreira 1998. Surface projection of a horizontal section of the Morro Velho Mina Grande deposit is shown in Fig. 7)

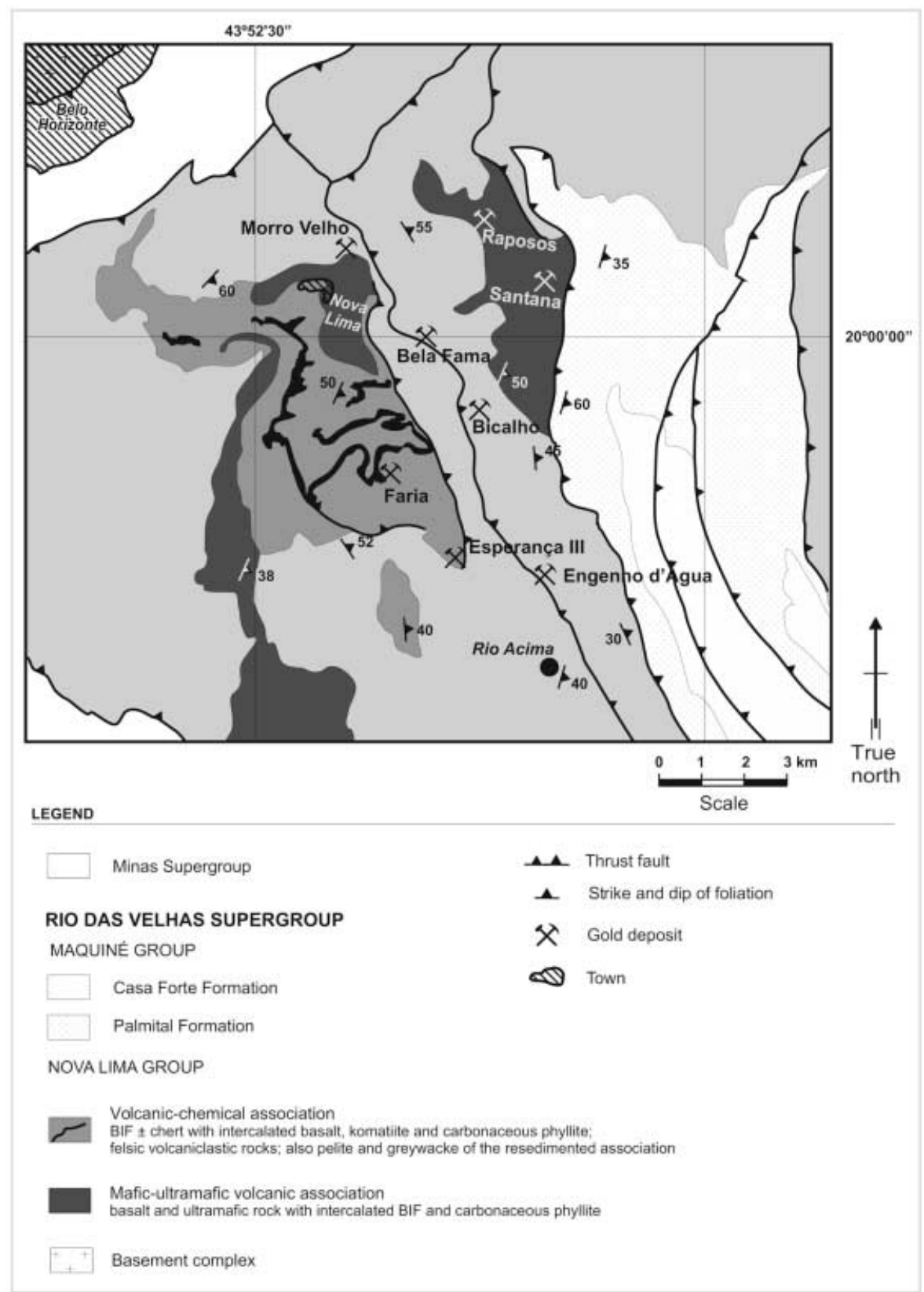

